\title{
PORTS MINIMIZATION WITH MINI-PORT AND LIVER FLEXIBLE RETRACTOR: AN ERGONOMIC AND AESTHETIC ALTERNATIVE FOR SINGLE PORT IN LAPAROSCOPIC GASTRIC BYPASS
}

\author{
Minimização de portais com miniportes e afastador flexível de fígado: alternativa ergonômica e estética ao single port em \\ bypass gástrico laparoscópico
}

Luiz Gonzaga de MOURA-JÚNIOR, Heládio Feitosa de CASTRO-FILHO, Francisco Heine Ferreira MACHADO Rodrigo Feitosa BABADOPULOS, Francisca das Chagas FEIJÓ, Silvana Duarte FERNANDES

From the Núcleo do Obeso do Ceará Serviço de Cirurgia Bariátrica e Metabólica de Fortaleza (Obese Nucleus of Ceará, Service of Metabolic and Bariatric Surgery), Fortaleza, CE, Brazil.
ABSTRACT - Background: The laparoscopic access, with its classically known benefits, pushed implementation in other components, better ergonomy and aesthetic aspect. Aim: To minimize the number and diameter of traditional portals using miniport and flexible liver retractor on bariatric surgery. Method: This prospective study was used in patients with less than $45 \mathrm{~kg} /$ $\mathrm{m}^{2}$, with peripheral fat, normal umbilicus implantation, without previous abdominoplasties. Were used one $30^{\circ}$ optical device with $5 \mathrm{~mm}$ in diameter, four accesses (one mini of $3 \mathrm{~mm}$ to the left hand of the surgeon, one of $5 \mathrm{~mm}$ to the right hand alternating with optics, one of 12 $\mathrm{mm}$ for umbilical for surgical maneuvers as dissection, clipping, in/out of gauze, and one portal of $5 \mathrm{~mm}$ for the assistant surgeon), resulting in a total of $25 \mathrm{~mm}$ linear incision; additionally, one flexible liver retractor (covered with a nelaton probe to protect the liver parenchyma, anchored in the right diaphragmatic pillar and going out through the surgeon left portal) to visualize the esophagogastric angle. Results: In selected patients (48 operations), gastric bypass was performed at a similar time to the procedures with larger diameters ( 5 or 6 portals and $10 \mathrm{~mm}$ optics, with sum of linear incision of $42 \mathrm{~mm}$ ) including oversuture line on excluded stomach, gastric tube and mesenteric closing. The non sutured portal of $3 \mathrm{~mm}$ and the two of $5 \mathrm{~mm}$ with subdermal sutures, were hardly visible in the folds of the skin; the one of $12 \mathrm{~mm}$ was buried inside the umbilicus or in the abdominoplasty incision. Conclusion: Minimizing portals is safe, effective, good ergonomic alternative with satisfactory aesthetic profile without need for specific instruments, new learning curve and limited movement of the instruments, as required by the single port.
HEADINGS - Gastric bypass. Human engineering.
RESUMO - Racional: A via de acesso laparoscópica com os seus benefícios classicamente conhecidos impulsionou a busca de outros componentes, de ordem estética e ergonômica. Objetivo: Minimizar o número e o diâmetro dos portais tradicionais utilizando miniporte e afastador flexível de fígado. Método: Estudo prospectivo, destinado a pacientes com IMC menor que $45 \mathrm{~kg} / \mathrm{m}^{2}$, perfil de gordura periférica, implantação normal do umbigo, com ou sem abdominoplastia. Foram utilizados ótica de 30 graus de $5 \mathrm{~mm}$ de diâmetro, quatro portais (um mini portal de $3 \mathrm{~mm}$ para a mão esquerda do cirurgião, um de $5 \mathrm{~mm}$ para a mão direita alternando com a ótica, um de $12 \mathrm{~mm}$ no umbigo para grampeamento, clipagem, entrada e saída de gaze, um portal de $5 \mathrm{~mm}$ para o cirurgião auxiliar), com somatória linear de 25 $\mathrm{mm}$ de incisão, um afastador flexível de fígado (fio de seda zero enluvado em $7 \mathrm{~cm}$ de sonda de nelaton para proteger o parênquima hepático pelo fio, ancorado no pilar diafragmático direito e saindo pelo portal esquerdo do cirurgião) para visibilizar o ângulo esofagogástrico. Resultado: Nos pacientes selecionados (48 operações), o bypass gástrico foi realizado em tempo assemelhado aos de paciente com IMC elevado com portais de diâmetros maiores (5 ou 6 portais e ótica de $10 \mathrm{~mm}$, com somatória linear de $42 \mathrm{~mm}$ de incisão), inclusive realizando sobressutura das linhas de grampo do estômago excluso, do tubo gástrico e fechamento das brechas mesentéricas. O portal de $3 \mathrm{~mm}$ não suturado e os dois de $5 \mathrm{~mm}$ com sutura subdérmica ficaram quase imperceptíveis na dobra da pele; o de $12 \mathrm{~mm}$ foi sepultado dentro do umbigo ou na incisão da abdominoplastia. Conclusão: A minimização de portais é alternativa segura, eficaz, ergonômica, com perfil estético satisfatório, sem necessidade de instrumentais específicos, de nova curva de aprendizado e a movimentos limitados dos instrumentos, como exige o single port.
DESCRTORES - Derivação gástrica. Engenharia humana.

\section{INTRODUCTION}

$T$ he laparoscopic access has its well known benefits - lower inflammatory response to trauma, less postoperative pain, early mobilization, better lung expansion - in minimizing risk of thromboembolism, atelectasis and pneumonia. The loops handling done with tweezers reduces contact, adhesions, ileus and facilitates the intestinal transit return. The pneumoperitoneum positive pressure decreases bleeding of small vessels, favors the dissection of structures and helps the maintenance of luminal fluid into the lumen and, so, preventing peritoneal contamination. The small incisions reduce bleeding, lipolysis, infection, exposure of the organs to the external environment, the formation of abdominal wall hernias $(0.2 \%$ in laparoscopic access compared with laparomic - $8 \%)$. Also, the puncture and the withdrawal of trocars time is shorter than dieresis and synthesis 
of the abdominal wall ${ }^{9}$.

The association of so many benefits, boosted the search for additional components, so as aesthetic appearance obtained with small incisions - some non noticeable or being camouflaged in the umbilicus, as "single port" incisions, or digestive and gynecological abdominal entrance proposed by NOTES. Technical improvements with robotics and its three-dimensional vision were also obtained, offering better ergonomy, precise movements, access to small spaces and elimination of the natural tremors ${ }^{1}$

The objective of this paper is to present surgical strategy that seeks to maintain the ergonomy, minimizing the number and diameter of five or six traditional portals - using miniportals and flexible liver retractor -, keeping stereotactic existing resources, with no need of new appliances or learning curve ${ }^{5}$, and getting the same results of the traditional laparoscopic technique with effectiveness, safety and aesthetic appearance of the single port access.

\section{METHOD}

All patients signed informed consent form, making them aware of the aesthetic benefit, the possibility of having to use the number of traditional portals and conversion to laparotomy. It is prospective and selective study aimed to patients with BMI lesser than $45 \mathrm{~kg} / \mathrm{m}^{2}$, with peripheral fat, with normal or with mild steatosis liver, normal implantation of the umbilicus, with or without previous abdominoplasty.

\section{Surgical technique}

Optical device of $30^{\circ}$ with $5 \mathrm{~mm}$ in diameter (Figure 1 ) and four miniportals were used: 1 ) one of $3 \mathrm{~mm}$ to the left hand of the surgeon; 2) one of $5 \mathrm{~mm}$ to the right hand alternating with the optics; 3) one of $12 \mathrm{~mm}$ at the umbilicus for stapling, making gastric tube, anastomoses, vessels clipping, in and out of gauze, and suture threads; 4) one of $5 \mathrm{~mm}$ to the assistant surgeon. The linear sum of all the incisions was $25 \mathrm{~mm}$ (Figure 2). To promote the lifting of the right liver lobe - anterior and laterally to the right to allow viewing of the esophagogastric angle and to protect against possible injury of hepatic parenchyma - a flexible liver retractor (Figure 3) was made using zero silk thread gloved with $7 \mathrm{~cm}$ of nelaton probe. It was placed in the operative field with an attachment point on the right diaphragmatic crus - lower anchor point - and getting off through the $3 \mathrm{~mm}$ trocar in the surgeon left portal. Thereafter, the trocar was reintroduced through the same portal, and the thread was externally anchored on the abdominal wall. Its handling and rectification permitted the elevation of the right lobe of the liver, exposing the esophagogastric angle.

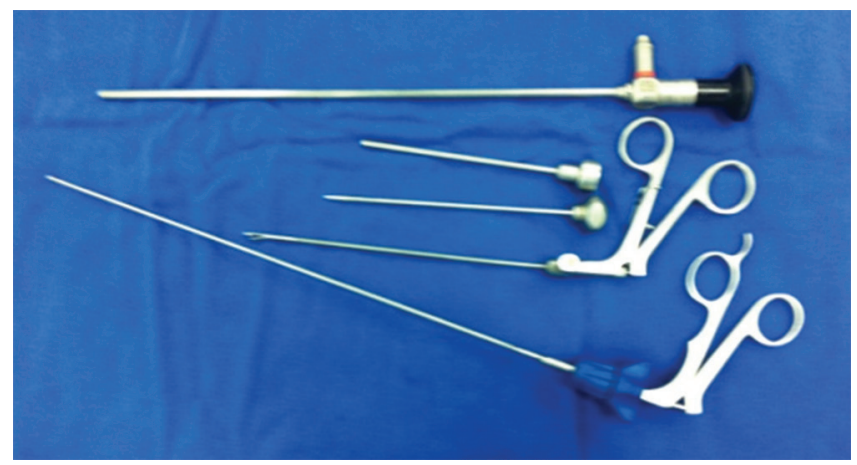

FIGURE 1 - Instruments: $30^{\circ}$ optic device, $3 \mathrm{~mm}$ trocars and forceps, and thread introducer

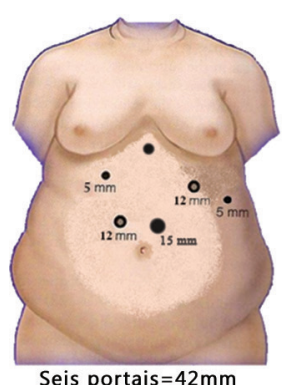

Seis portais $=42 \mathrm{~mm}$

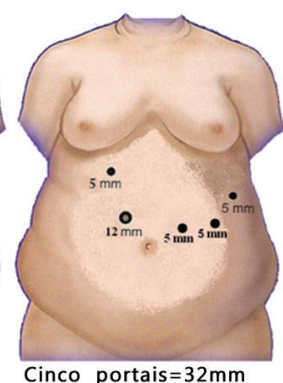

Cinco portais $=32 \mathrm{~mm}$

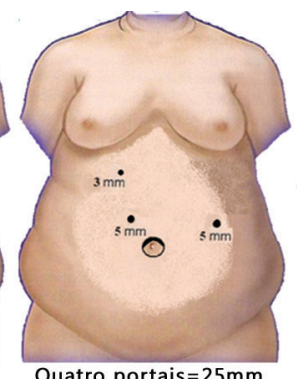

Quatro portais $=25 \mathrm{~mm}$
FIGURE 2 - Sum of the linear extension of several portals

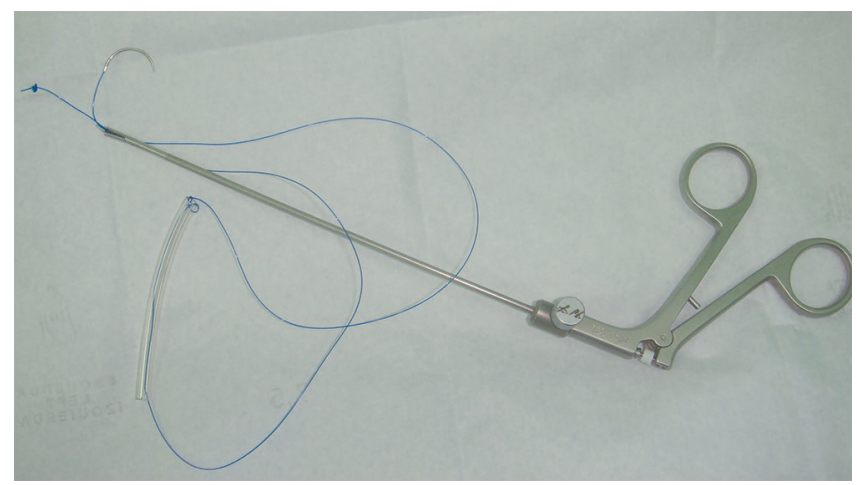

FIGURE 3 - Flexible liver retractor

\section{RESULTS}

In selected patients, the intra-abdominal findings confirmed the anatomical condition that would allow the proposed technique to proceed with minimization of portals and all operations were gastric bypass $(n=48)$; they were done without putting more portals or larger diameter. The procedure was performed at a similar time (median 90 minutes) of the patients with high BMI with larger diameters portals (five or six portals and optics of $10 \mathrm{~mm}$, with a linear sum of $42 \mathrm{~mm}$ incision). There was no change in the standardized technique, including performing oversuture on stapled line of the excluded stomach, the gastric tube, closure of mesenteric and other peritoneum apertures. The $3 \mathrm{~mm}$ portal did not need to be sutured; in the two $5 \mathrm{~mm}$ only were used subdermal sutures - which were hardly visible in the skin fold. The portal of 12 $\mathrm{mm}$ had aponeurosis sutured to prevent incisional hernia, and skin incision almost disappeared inside the umbilicus or was integrated in the abdominoplasty neoumbilicus.

\section{DISCUSSION}

The minimization of the portals became possible by the association of various technical and technological advances. The harmony of the members of the surgical team and the good level of relaxation of anesthesia, facilitated the operative times particularly after adapting to new movements ${ }^{8}$. The correct positioning of portals and technical methodization - gained with the long experience with gastroplasty -, were executed without any modification of the surgical technique already consecrated ${ }^{4}$.

The metal liver retractor requires puncture of 5 or 10 $\mathrm{mm}$; is an instrument that compresses, traumatizes and can fray the diaphragmatic crus with its jaw; it can also produces liver fracture. The flexible liver retractor leaving the portal from the left hand of the surgeon, saves one puncture. In facing hepatomegaly and left lobe as a tent, the retractor can be placed in a $V$ format (Figure 4), offering a tunnel till the esophagogastric angle. The retractor model presented was 
designed in the surgeon's service. It is practical, reproducible, requires little runtime in fixing it in the diaphragmatic crus and is of low operative cost (consumes 2.0 needled thread and 7 $\mathrm{cm}$ of nelaton probe). This flexible retractor have been used in more than 800 gastric bypass, without any injury to the diaphragmatic crus and hepatic tissue ${ }^{5}$.

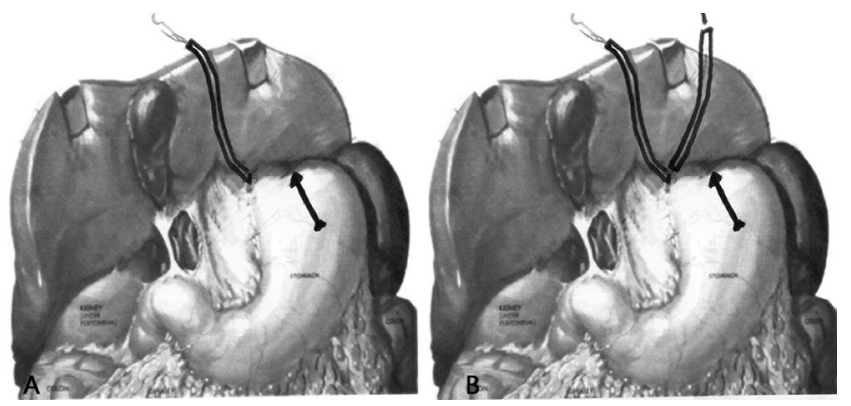

FIGURE 4 - Flexible liver retractor: a) one band and b) $V$ band format

Despite the assurance of the staplers industries that the triple staple line promotes safe synthesis of gastric edges after clipping, and referring that bleeding and fistulas - the two major villains of the surgeon - are more a technical flaw that technological one, the option the this surgical team is to oversuture the staples lines, offering greater efficiency and safety by reducing the risk of complications. The most frequent causes of these risks are: gastroparesis of the excluded stomach with distention and high pressure; extensive vomiting; bleeding from the staple line; decrease in wound area; and failure on clipping. Better ability on doing endosutures, gained over time, favors and also improves the quality of the sutures that are performed in other operative steps ${ }^{3}$.

The technological advances of endoscopy devices, the endostaplers with their joints and their varying sizes, allowed operative field in greater distance. The decrease in the diameter of the optics, from 10 to $5 \mathrm{~mm}$, while maintaining the same image quality, allowed the use of portals also thinner. The adaptation of the tweezers with small diameter (3 $\mathrm{mm})$, flexible, articulated, enabled abdominal access with increasingly smaller portals. Uni and bipolar energy coagulators, ultrasonic scissors for dissection and division of tissue, also helped in injury decrease ${ }^{2,6}$.

The already proposed single port requires an umbilical incision between 30 and $40 \mathrm{~mm}$, one minilaparotomy over the aponeurosis of the rectus abdominis muscle to introduction of the trocar, and long optical devices. As the current instruments have limited movements, they can present overlap or even reverse movements, competing with each other in a long distance. This fact requires new adaptation of the surgical team, new ergonomic position, and the need for longer and articulated instruments development. Formed by the pneumoperitoneum, the ceiling between the abdominal wall and the viscera is decreased compromising movement and visibility over the anatomical structures. Is not established yet the rate of incisional hernia formation - the cut point - and if the inflammatory response to trauma is likely the one of laparotomic or laparoscopic approaches, and, finally, if the aesthetic proposal brings real advantages over conventional portals. The single port uses minilaparotomy of $30-40 \mathrm{~mm}$ in the umbilical region, modify the operative technique, increases the time for laparorrhaphy, causes more postoperative pain, and presents risk of incisional hernia formation, infection and deformation of the umbilicus.

The placement of the flexible liver retractor does not increase the operative time and is easy to perform in any laparoscopic procedure of the upper abdomen (gastric bypass, sleeve gastrectomy, cholecystectomy, Nissen fundoplication and Heller esophagocardiomyotomy) and even assists single port and robotics, facilitating the visualization of the esophagogastric angle.

Run the two alternative routes of access (minimized portals and single port) may be valid to extend the technical and tactical skills of the surgical team.

\section{CONCLUSIONS}

Minimizing portals is safe, effective, ergonomic, with satisfactory aesthetic alternative profile, without requiring specific instrumental, new curve or limited by current movements of the instruments.

\section{REFERENCES}

1. Elias, AA. Gastrectomia vertical robótica - Padronização da técnica Arq Bras Cir Dig. ABCD Arq Bras Cir Dig. 2011; 24 (Suplemento 1): 21.

2. Hamad, GG. Operating room setup and instrumentations Cap 7. Pg 55-60. Laparoscopic Bariatric Surgery. Sayed Ikramuddin, MD et al. 2005 by Lippincot Williams \& Wilkins.

3. Leonardi, PC; Zilbenstein, B; Jacob, CE; Yagi, O; Cecconelo, I. Nós e suturas em vídeocirurgia, orientações práticas e técnicas- $A B C D$ Arq Bras Cir Dig. 2010 - V.23 N.3 p200-205.

4. Madan, AK; Harper, J; Tichansky, DS. Techniques or laparoscopic gastric bypass: a survey or ASBS practice in surgeons - Abstracts: 2007 Plenary Sessions \Surgery for Obesity and Related Diseases 3 (2007) 297 n. 577.

5. Moura Jr, LG ; Feitosa, HC; Machado,FHF; Babadopulos, RF; Feijó, FC; Fernandes, SD. Minimizing portals with liver malleable retractor in bariatric laparoscopic acess, N.O.T.E.S. robotic. P.21 - Poster Sessions -5 th Congress of the International Federation for the Surgery of Obessity and Metabolic Disorders European Chapter (IFSO-EC) Barcelona April, 26-28, 2012.

6. Moura Jr, LG ; Feitosa, HC; Machado,FHF; Babadopulos,RF; Feijó, FC; Fernandes, SD. Colecistectomia pós operatória: minimização de portais usando a mesma via de acesso da gastroplastia. Pg 18 ABCD - Arq Bras Cir Dig. Vol 24 - Suplemento 1 - pg 18 - 2011.

7. Ramos, AC; Galvão Neto, MP; Ramos, MG; Silva, ACS; Galvão, TD; Gordejuela, AGR; Gebelli, GP. Gastrectomia vertical por single porte - Técnica. ABCD Arq Bras Cir Dig. 2011, 24 (Suppl. 1) 21.

8. Schauer, P; Ikramuddin, S; Hamad, G; Gourash, W. The learnin curve for laparoscopic ROUX-EN-Y gastric bypass is 100 cases. Surg. Endosc. 17:212 -2003.

9. Tinoco RC; Tinoco ACA. - A via laparoscópica em cirurgia bariátrica. Cap. 24. P173-177 - Cirurgia da Obesidade. Sociedade Brasileira de Cirurgia Bariátrica. Editor Arthur B. Garrido Júnior. São Paulo: Editora Atheneu, 2002. 